\title{
ТЕОРЕТИКО-ПРАКТИЧНА ПІДГОТОВКА МАЙБУТНІХ ПЕДАГОГІВ ЗАКЛАДІВ ДОШКІЛЬНОЇ ОСВІТИ ДО РЕАЛІЗАЦІЇ ІНТЕРАКТИВНИХ ТЕХНОЛОГІЙ В ІНКЛЮЗИВНОМУ ОСВІТНЬОМУ СЕРЕДОВИЩІ
}

Висвітлюються основні засади змісту теоретичної та практичної підготовки майбутніх педагогів закладів дошкільної освіти до реалізації інтерактивних технологій в інклюзивному освітньому середовищі. Проаналізовано специфіку впровадження інтерактивних технологій в інклюзивному освітньому середовищі закладів дошкільної освіти. Охарактеризовано проблему підготовки майбутніх педагогів закладів дошкільної освіти до реалізаиї інтерактивних технологій в інклюзивному освітньому середовищі.

Розкрито програмно-методичний супровід змісту дошкільної освіти дітей з особливими освітніми потребами. У статті подано аналіз Базового компонента дошкільної освіти в Україні, у якому розкрито основні освітні лінії, за якими відбуваються навчання та виховання дітей дошкільного віку у всіх закладах дошкільної освіти незалежно від типів і форм підпорядкування. Оиінено можливості для формування професійної готовності майбутніх педагогів закладів дошкільної освіти до організаиії освітнього процесу з дітьми дошкільного віку в інклюзивному освітньому середовищі. На основі аналізу освітніх стандартів виявлено причини, ио сприяють иілісному формуванню професійноі готовності майбутніх педагогів закладів дошкільної освіти.

Проаналізовано використання інтерактивних методів під час навчання дітей з особливими освітніми потребами.

Розглянуто проблемні питання організації інклюзивної освіти в закладах дошкільної освіти; використання інтерактивних технологій у роботі з дітьми з особливими освітніми потребами та особливості інклюзивного навчання в базових закладах.

Розкрито класифікацію інтерактивних технологій за формами навчання, у яких вони реалізуються.

Висвітлено актуальність використання інтерактивних технологій в освітньому процесі закладу дошкільної освіти, зокрема в роботі з інклюзивною групою.

Досліджено основні критерії під час відбору якісних мультимедійних розробок.

Ключові слова: інклюзивне освітнє середовище, інтерактивні технологї, електронний освітній ігровий ресурс, мультимедійна презентація, мультиплікаиійний фільм.

Якісна дошкільна освіта сприяє розвитку інклюзивної освіти - освіти, яка передбачає участь в освітньому процесі всіх дітей і створює для цього відповідні можливості. Сучасний заклад дошкільної освіти базується на демократичних цінностях і повазі до основних прав людини і створює умови для максимальної участі в освітньому процесі всіх дітей, зокрема й дітей з особливими освітніми потребами. Середовище має великий вплив на розвиток дитини в усіх сферах - фізичній, когнітивній, соціально-емоційній, розвитку мовлення та ін. Створюючи фізично і психологічно безпечне й стимулювальне середовище та забезпечуючи різноманітні ресурси, педагог сприяє розвитку й навчанню дітей через самостійне і групове дослідження, гру, взаємодію з іншими дітьми та дорослими. Піклуючись про те, щоб кожна дитина відчувала, що у групі ій раді, педагог так виховує в дітей повагу до кожної окремої людини; допомагає дітям зрозуміти, що кожна дитина та іï сім'я є важливою частиною спільноти дошкільної групи, що в кожної дитини є можливості користуватися загальними ресурсами і простором, брати участь у їх створенні і підтримці.

Забезпечуючи дітям безпечне середовище й адаптуючи його 3 урахуванням конкретних навчальних потреб, педагог сприяє тому, щоб діти діяли у співпраці, брали участь у різних заняттях і завданнях, не боялися ризикувати і братися за більш складні завдання як в освітньому процесі, так і в повсякденних ситуаціях [7, c. 16-17].

3 метою організації успішного освітнього процесу в інклюзивному освітньому середовищі заклади дошкільної освіти впроваджують інтерактивні технології. Суть інтерактивних технологій полягає в постійній, активній взаємодії всіх учасників освітнього процесу, що виявляється у спілкуванні, обміні інформацією, спільному розв'язанні проблем, моделюванні ситуацій, оцінюванні дій колег і власної поведінки. Інтерактивні технології допомагають задіяти не тільки досвід, свідомість дитини, але й ії̈ почуття, вольові риси та емоції. I це дуже важливо. Чим сильніше дитина сприймає, переживає, відчуває предмети та явища навколишнього світу, тим краще вона усвідомлює їхню суть, тим надійніше вони закріплюються в досвіді її поведінки та діяльності [6, с. 2-3].

Ми цілком поділяємо слушну думку науковців, які зазначають, що в Україні за останні десятиріччя було здійснено вдосталь досліджень проблеми підготовки майбутніх педагогів закладів дошкільної освіти. Аналіз наукових джерел дає змогу констатувати, що в наукових працях Г. Бєлєнької висвітлено сутність і структуру фахової компетентності педагога закладу дошкільної освіти; потребу використання просвітницько-консультативної роботи вихователів із батьками дітей раннього віку обгрунтувала у своїх дослідженнях Г. Борин; Л. Загородня акцентувала проблему змісту, форм, методів, етапів та умов формування в студентів дошкільного факультету основ педагогічної техніки; Л. Зданевич з'ясувала підготовку майбутніх вихователів закла- 
дів дошкільної освіти до роботи з дезадаптованими дітьми; у дисертації Н. Сайко дослідила зміст, форми та методи професійної підготовки майбутніх вихователів закладів дошкільної освіти до соціалізації дітей дошкільного віку шляхом виховання гармонійного світосприймання.

Дослідженню проблеми залучення дітей з особливими освітніми потребами до навчання в загальноосвітніх закладах присвячено праці В. Авілова, В. Бондара, І. Демченко, О. Євтухової, В. Зарецького, І. Іванової, Н. Козлова, А. Колупаєвої, І. Купрієвої, В. Ляшенко, О. Мартинчук, Ю. Найди, В. Синьова, О. Столяренко, Н. Судакової, О. Таранченко, Є. Чайковського та ін.

Водночас проблема підготовки майбутніх педагогів закладів дошкільної освіти до реалізації інтерактивних технологій в інклюзивному освітньому середовищі ще не вдосталь досліджена як у теоретичному, так і в практичному аспектах.

Мета статті - дослідження інтерактивних технологій в інклюзивному освітньому середовищі закладів дошкільної освіти.

Діти з особливими освітніми потребами - поняття, яке широко охоплює всіх дітей, чиї освітні потреби виходять за межі загальноприйнятної норми. Йдеться про дітей із особливостями психофізичного розвитку, обдарованих, а також дітей із соціально вразливих груп (вихованців дитячих будинків та ін.).

Розглядаючи питання навчання та виховання дітей дошкільного віку з особливими потребами в закладах дошкільної освіти, ми хочемо звернути увагу на те, що застосування інтерактивних технологій під час інклюзивного навчання та виховання буде сприяти інтеграції такої дитини в суспільство однолітків, компенсації іiї фізичних недоліків засобами інноваційних інформаційних технологій, що загалом повинно позитивно позначитися на формуванні ії особистості. Розглядаючи особистість як засіб функціонування людини в суспільстві, ми не ізолюємо їі в спеціалізованому закладі освіти, а повною мірою долучаємо до всіх видів суспільних зв'язків, починаючи з дошкільного віку.

Загальними правовими підставами для зарахування дітей із особливими освітніми потребами до загальноосвітнього закладу дошкільної освіти є: Закон України «Про освіту», Закон України «Про дошкільну освіту», Положення про дошкільний навчальний заклад (затверджене Постановою Кабінету Міністрів України № 305 від 12 березня 2003 р.), Наказ МОН і МОЗ України «Про затвердження Порядку комплектування інклюзивних груп у дошкільних навчальних закладах» від 6 лютого 2015 р. № 104/52, Лист МОН України «Щодо організації діяльності інклюзивних груп у дошкільних навчальних закладах» від 12жовтня 2015 р. № 1/9-487».

Програмно-методичний супровід змісту дошкільної освіти дітей з особливими освітніми потребами здійснюється за окремими програмами і методичними розробками, рекомендованими МОН України або схваленими відповідними предметними комісіями Науково-методичної ради з питань освіти МОН України, інформація про які розміщена на сайті МОН України.

У дошкільній освіті навчально-виховним орієнтиром, яким керується педагогічний колектив у наданні освітніх послуг, є «Базовий компонент дошкільної освіти в Україні», у якому подано основні освітні лінії, за якими відбувається навчання та виховання дітей дошкільного віку у всіх закладах дошкільної освіти незалежно від типів і форм підпорядкування. Так, інваріативна частина «Базового компонента» містить такі освітні лінії: «Особистість дитини», «Дитина в соціумі», «Дитина у природному довкіллі», «Дитина в світі культури», «Гра дитини», «Дитина в сенсорно-пізнавальному просторі», «Мовлення дитини». До варіативної частини внесено такі освітні лінії: «Комп’ютерна грамотність», «Іноземна мова» та «Шахи». Організація освітнього процесу з дітьми з особливими потребами дошкільного віку може відбуватися шляхом поєднання інваріативного складника та варіативного. Зокрема, для розвитку дитини за освітньою лінією «Дитина в світі культури» [1] можливо створювати презентації з урахуванням психічних і фізичних особливостей дітей. Звичайно, ми наполягаємо на тому, що таке навчання повинно бути особистісно-орієнтованим, bookmark120 враховувати здібності й інтереси самої дитини, доцільність використання технічних засобів, бути всебічно обгрунтованим із таких позицій: вік дитини, у чому саме полягають її особливі потреби, забезпеченість іiі та закладів дошкільної освіти технічними засобами, відповідність матеріалу рівню психічного розвитку дитини.

Навчання та виховання дітей з особливими потребами враховане в загальних програмах. Наприклад, програма «Дитина» містить розділ «Діти з особливими потребами». Також існують спеціальні програми навчання та виховання дітей з особливими освітніми потребами [2].

У контексті інклюзивної освіти педагогічна технологія охоплює всі аспекти, елементи педагогічної системи - від постановки цілей до проєктування всього освітнього процесу й перевірки його результативності.

Технології навчання в інклюзивному освітньому середовищі можна розподілити на групи: інтерактивні технології корпоративного навчання; технології колективно-групового навчання; технології ситуативного моделювання; технології опрацювання дискусійний питань.

До основних інтерактивних технологій, що доцільно використовувати в освітньому процесі закладу дошкільної освіти, зокрема в роботі з інклюзивною групою (старша вікова група, діти 5-6 років), відносимо такі:

1. Мультимедійна презентація - набір слайдів за певною тематикою, що зберігається у файлі спеціального формату. Водночас кожний слайд може містити текстові, графічні, табличні дані, анімацію, аудіо, відео 
та інше. Цей засіб дає змогу комбінувати звук і зображення в динаміці, що сприяє активізації довільної уваги дитини. Одночасний вплив на два найважливіші органи сприйняття - слух і зір - дає змогу досягти більшого ефекту. Вважаємо доцільним застосовувати мультимедійні презентації під час вивчення нових понять або їх закріплення.

2. Електронний освітній ігровий ресурс - це окремий вид ігрового програмного забезпечення, розроблений для розв'язання дидактичних завдань. Згідно з [4], електронний освітній ігровий ресурс - це програмне забезпечення, що поєднує пізнавальну та розважальну функції, містить завдання в ігровій формі та спрямоване на активізацію пізнавальної діяльності дітей. Мета використання електронного освітнього ігрового ресурсу має подвійний зміст: ігровий - одержання дитиною «винагороди» після досягнення ігрової мети; навчальний і розвивальний - набуття й розвиток знань, умінь і навичок. Під час гри в дітей розвиваються позитивні емоційні реакції, прагнення досягати поставленої мети, що сприяє корекції та розвитку психічних процесів.

Важливо пам'ятати, що така гра є суто доповненням до основних видів діяльності дитини, і в жодному разі не повинна витіснити традиційну гру (сюжетно-рольову, міжособистісну).

3. Мультиплікаційний фільм - продукт мультиплікації, створений шляхом зйомки послідовних фаз руху об’єктів. 3 перегляду мультфільмів діти отримують значні обсяги даних художньо-естетичного, моральноетичного, пізнавального та іншого характеру [3, с. 16-18]. Їх упровадження в освітній процес дає змогу позитивно впливати на засвоєння способів поведінки, алгоритмів досягнення цілей, розвиток емоційної сфери і психічних процесів (мислення, пам'яті, уваги, уяви тощо). Перегляд мультфільму (або його фрагменту) повинен розпочинатися вступним словом вихователя, підготовкою дітей до основної смислової лінії й завершуватися поставкою вихователем проблемних запитань, а також наданням можливості дітям висловити власні почуття, відношення, рефлексію побаченого. Вважаємо доцільним демонструвати мультиплікаційні фільми для пояснення і формування складних комплексних понять: морально-етичних цінностей, норм соціальної взаємодії та іншого.

Незважаючи на це, у вільному доступі можливо відшукати якісні мультимедійні розробки. Водночас під час їх відбору важливо керуватися низкою основних критерї̈, серед яких ми визначаємо такі: простота інсталяції або наявність вебдоступу; можливість запуску на основі операційної системи Windows (для ПК) та Android (для мобільних пристроїв), що на сьогодні є основними платформами у вітчизняних закладах освіти; просте зрозуміле управління; ергономічний дизайн, приємна кольорова гама та звуковий супровід, відсутність занадто яскравих кольорів і різких звуків; якісний голосовий супровід (чітка дикція, розмірений темп, приємний тембр); наявність україномовної версії; спрямованість на формування й розвиток у дітей знань, умінь і навичок, визначених у державному стандарті дошкільної освіти.

Залучення дітей до якісного освітнього середовища з ранніх років має позитивний вплив на їх подальше навчання й соціалізацію. Так, згідно з результатами дослідження Національного об'єднаного комітету 3 питань навчання дітей з особливими потребами США (National Joint Committee on Learning Disabilities), було встановлено, що діти з особливими освітніми потребами, які мали доступ до якісних освітніх послуг у ранньому віці, демонструють більш високі навчальні результати в початковій школі [5, с. 95-102].

Педагогічно обгрунтоване й виважене використання інтерактивних технологій відкриває широкі можливості для поліпшення якості дошкільної освіти, іiі доступності, сприяючи рівному доступу до освітніх послуг, плідній суспільній інтеграції на засадах інклюзивного підходу. Водночас потрібною умовою є готовність педагогічних працівників до розроблення інтерактивних методів.

Висновки. Отже, поєднання теоретичної та практичної підготовки майбутніх педагогів закладів дошкільної освіти до реалізації інтерактивних технологій в інклюзивному освітньому середовищі характеризується синтезом теоретичних інклюзивних знань, практичних навичок і вмінь, особистісно-значущих і професійно важливих якостей, потрібних для готовності успішно здійснювати педагогічну діяльність і здатності користуватися ними для розв'язання стандартних і нестандартних психолого-педагогічних ситуацій і проблем, пов'язаних $з$ освітою дітей з особливими освітніми потребами в інклюзивному освітньому середовищі закладу дошкільної освіти.

\section{Використана література:}

1. Базовий компонент дошкільної освіти. URL: https://mon.gov.ua/storage/app/media/doshkilna/bazovij-komponent-doshkilnoyiosviti-na-sajt-ostatochnij.pdf (дата звернення: 11.06.2018).

2. Дитина: Програма виховання і навчання дітей від двох до семи років / Бєлєнька Г. В. та ін. Київ : ун-т ім. Б. Грінченка, 2017. $492 \mathrm{c}$.

3. Коваленко В. В. Мультиплікаційна продукція як засіб формування соціальної компетентності учнів молодших класів. Освіта та розвиток обдарованої особистості. 2016. № 8 (51). С. 16-18.

4. Литвинова С. Г., Мельник О. М. Використання електронних освітніх ігрових ресурсів у навчально-виховному процесі початкової школи : метод. рекоменд. Київ : Компринт, 2016. 85 с.

5. Носенко Ю. Г., Матюх Ж. В. Зарубіжний досвід використання інформаційно-комунікаційних технологій в інклюзивній дошкільній освіті. Нова педагогічна думка. 2015. № 4 (84). С. 95-102.

6. Ониськів М. С., Білінська О. С. Використання інтегрованих технологій у процесі особистісно-зорієнтованого навчання дітей з особливими освітніми потребами. Дитина з особливими потребами. 2019. № 2. С. 2-3.

7. Софій Н. 3., Найда Ю. М. Середовище, що належить дітям: порадник для педагогів закладів дошкільної освіти. Київ : ЮНІСЕФ, ВФ «Крок за кроком», 2019. С. 16-17. 


\section{References:}

1. Bazovyi komponent doshkilnoi osvity [The basic component of preschool education]. (n.d.). mon.gov.ua/storage. URL: https://mon.gov.ua/storage/app/media/doshkilna/bazovij- komponent-doshkilnoyi-osviti-na-sajt-ostatochnij.pdf(data zvernennia: 11.06.2018) [in Ukrainian].

2. Bielienka H. V. (2017). Dytyna: Prohrama vykhovannia i navchannia ditei vid dvokh do semy rokiv [Child: The program of education and training of children from two to seven years]. Kyiv : un-t im. B. Hrinchenka [in Ukrainian].

3. Kovalenko V. V. (2016). Multyplikatsiina produktsiia yak zasib formuvannia sotsialnoi kompetentnosti uchniv molodshykh klasiv [Cartoon production as a means of forming social competence of junior students]. Osvita ta rozvytok obdarovanoi osobystostiEducation and development of a gifted personality, 8 (51), 16-18 [in Ukrainian].

4. Lytvynova S. H., Melnyk O. M. (2016). Vykorystannia elektronnykh osvitnikh ihrovykh resursiv u navchalno-vykhovnomu protsesi pochatkovoi shkoly: metod. Rekomend [The use of electronic educational game resources in the educational process of primary school: a method. Recommend]. Kyiv: Komprynt [in Ukrainian].

5. Nosenko Yu. H., Matiukh Zh. V. (2015). Zarubizhnyi dosvid vykorystannia informatsiino-komunikatsiinykh tekhnolohii v inkliuzyvnii doshkilnii osviti [Foreign experience in the use of information and communication technologies in inclusive preschool education]. Nova pedahohichna dumka - New pedagogical thought, № 4 (84), 95-102 [in Ukrainian].

6. Onyskiv M. S., Bilinska O. S. (2019). Vykorystannia intehrovanykh tekhnolohii u protsesi osobystisno-zoriientovanoho navchannia ditei z osoblyvymy osvitnimy potrebamy [The use of integrated technologies in the process of personality-oriented learning of children with special educational needs]. Dytyna z osoblyvymy potrebamy - A child with special needs, № 2, 2-3 [in Ukrainian].

7. Sofii N. Z., Naida Yu. M. (2019). Seredovyshche, shcho nalezhyt ditiam: poradnyk dlia pedahohiv zakladiv doshkilnoi osvity [Child-friendly environment: a guide for preschool teachers]. Kyiv: VF "Krok za krokom" [in Ukrainian].

Tokar L. P., Shevchenko L. S. Combination of theoretical and practical training of future teachers of preschool education institutions for the implementation of interactive technologies in an inclusive educational environment

The article highlights the basic principles of the content of theoretical and practical training of future teachers of preschool education institutions for the implementation of interactive technologies in an inclusive educational environment. The specifics of the introduction of interactive technologies in the inclusive educational environment of preschool institutions are analyzed. The problem of preparation of future teachers of preschool institutions for the implementation of interactive technologies in an inclusive educational environment is described.

The program-methodical support of the content of preschool education of children with special educational needs is revealed. The article presents an analysis of the Basic component of preschool education in Ukraine, which reveals the main educational lines along which the education and upbringing of preschool children in all preschool institutions, regardless of the types and forms of subordination. Opportunities for the formation of professional readiness of future teachers of preschool institutions to organize the educational process with preschool children in an inclusive educational environment are assessed. Based on the analysis of educational standards, the reasons that contribute to the holistic formation of professional readiness of future teachers of preschool education are identified.

The use of interactive methods during the education of children with special educational needs is analyzed.

The problematic issues of the organization of inclusive education in preschool education institutions are considered; the use of interactive technologies in working with children with special educational needs and features of inclusive education in basic institutions.

The classification of interactive technologies according to the forms of education in which they are implemented is revealed.

The relevance of the use of interactive technologies in the educational process of preschool education, in particular in working with an inclusive group.

The main criteria for the selection of high-quality multimedia developments are studied.

Key words: inclusive educational environment, interactive technologies, electronic educational game resource, multimedia presentation, cartoon. 